\title{
ANALIZA DOSTĘPNOŚCI NIEKTÓRYCH OBIEKTÓW UŻYTECZNOŚCI PUBLICZNEJ DLA OSÓB NIEPEŁNOSPRAWNYCH
}

\author{
Wojciech Drozd ${ }^{\varpi}$ \\ Wydział Inżynierii Lądowej, Politechnika Krakowska, Kraków
}

\begin{abstract}
STRESZCZENIE
W artykule przedstawiono wybrane aspekty oceny dostępności obiektów użyteczności publicznej dla osób niepełnosprawnych. W tym kontekście przedstawiono wyniki badań przeprowadzonych na grupie osób niepełnosprawnych, identyfikując bariery architektoniczne dla nich w obiektach użyteczności publicznej aglomeracji krakowskiej. Wyniki ankiet pozwoliły także zapoznać się z ogólnymi badanych w zakresie dostępności budynków dla osób niepełnosprawnych. Z uwagi na wagę i skalę problemu oraz znikomą liczbę publikacji na ten temat podjęte badania wydają się być jak najbardziej potrzebne i uzasadnione.
\end{abstract}

Słowa kluczowe: osoby niepełnosprawne, obiekty użyteczności publicznej, dostępność

\section{WSTĘP}

Równość wszystkich obywateli wobec prawa zagwarantowana jest zarówno w Konstytucji Rzeczpospolitej Polskiej, jak i w Karcie Praw Osób Niepełnosprawnych. $\mathrm{Z}$ obydwu tych aktów wynika, że nikt z żadnej przyczyny, a więc także z powodu niepełnosprawności fizycznej, psychicznej lub podeszłego wieku nie może być dyskryminowany. Wszyscy mają prawo do niezależnego, samodzielnego i aktywnego życia prywatnego, zawodowego i społecznego w środowisku bez barier utrudniających wygodne mieszkanie, wykonywanie zawodu, zabawę i wypoczynek. Dotyczy to barier nie tylko utrudniających, ale czasem wręcz uniemożliwiających dowolny wybór miejsca nauki i pracy, bezpieczne przemieszczenie się i korzystanie ze środków transportu.

Tymczasem niewiele osób zdaje sobie sprawę z rozmiarów problemu dostępności wybranych obiektów użyteczności publicznej dla osób niepełnosprawnych. Według Rocznika Demograficznego z 2017 roku (GUS 2017) w Polsce zanotowano około $6 \mathrm{mln}$ osób niepełnosprawnych, a w państwach Unii Europejskiej szacuje się, że niepełnosprawność w jakiejkolwiek formie dotyka około $10 \%$ ludności. Oznacza to około 37 mln w Europie, z których mniej więcej połowa znajduje się w wieku produkcyjnym. Statystyki mówią za siebie, ale w powszechnej świadomości skala problemu wydaje się mniejsza. Nie bez przyczyny tak się dzieje. Niepełnosprawni po prostu nie wychodzą z domu. Wokół napotykają tyle barier, że nie są w stanie włączyć się w normalne życie, zarówno w małych miejscowościach, jak i metropoliach. Ze skalą problemu niepełnosprawności wśród mieszkańców naszego kraju wiąże się bezpośrednio sprawa zagospodarowania przestrzennego miast, dzielnic, osiedli, a także odpowiedniego wyposażenia znajdujących się tam obiektów. Polskie

$\unrhd_{\text {wdrozd@ztob.pk.edu.pl }}$ 
miasta dalej są pełne barier architektonicznych dla osób o różnym stopniu niepełnosprawności - począwszy od urzędów, szpitali, szkół, a kończąc na miejscach zamieszkania, czyli na najważniejszych przestrzeniach. Z raportu „Życie usłane schodami” (b.a., 2003) wynika, że w najbogatszym z polskich miast Warszawie zaledwie 7,6\% obiektów użyteczności publicznej jest całkowicie dostępnych dla ludzi mających problemy z poruszaniem się.

Wszystkie te liczby skłaniają do zastanowienia się nad sposobem dostosowania standardów życia zdrowej części społeczeństwa do potrzeb i możliwości osób niepełnosprawnych (Gołuch, 1995; GrabowskaPałecka, 2004). Bardzo często niepełnosprawny może być tak samo dobrym pracownikiem lub klientem jak inny człowiek, zatem pilnie należy zająć się problemem organizacji przestrzeni publicznej dla osób z niepełnosprawnością fizyczną (Jaranowska, 1983; Piasecki i Stępniak, 1998).

Oprócz właściwego podejścia architektów do projektowania obiektów budowlanych potrzebna jest też zmiana podejścia społeczeństwa i władz samorzadowych (Meyer-Bohe, 1998). Częste poruszanie problemu dostępności lub jej braku dla osób niepełnosprawnych na pewno pozwoli na zmianę podejścia osób w pełni sprawnych do tego tematu.

Mimo że osoby niepełnosprawne stanowią w Polsce około $10 \%$ populacji, niewielu $\mathrm{z}$ nich może niestety powiedzieć, że żyje w odpowiednich do swego stanu zdrowia warunkach. Nie robiono dotychczas kompleksowych badań pokazujących, ile procent obiektów i które z nich są w Polsce niedostępne dla osób niepełnosprawnych. Powód wydaje się prozaiczny: wszystkim przecież wiadomo, że stanowią one większość.

Celem niniejszego artykułu jest przedstawienie wyników badań przeprowadzonych wśród osób niepełnosprawnych oceniających stan dostosowania obiektów użyteczności publicznej do ich potrzeb oraz wniosków i konkluzji autora zajmującego się tymi zagadnieniami.

\section{PROBLEM NIEPEŁNOSPRAWNOŚCI W PRZEPISACH BUDOWLANYCH I WYKONAWSTWIE}

Wiodącym zbiorem przepisów regulujących wszelkie kwestie związane z projektowaniem, wykonawstwem i użytkowaniem obiektów budowlanych jest Prawo budowlane (Dz.U. 2013, poz. 1409). Zostało ono wprowadzone w celu przedstawienia wymagań dotyczących zarówno osób projektujących, jak i budujących, tak aby zachować ochronę publiczną, bezpieczeństwo i ogólny dobrostan. W myśl tej ustawy wszystkie budynki użyteczności publicznej muszą zapewnić dostępność dla osób niepełnosprawnych, a w szczególności dla osób poruszających się na wózkach inwalidzkich. Dotyczy to nie tylko budynków nowo wybudowanych, ale również budynków już istniejących.

W przypadkach szczególnie uzasadnionych dopuszcza się odstępstwo od przepisów techniczno-budowlanych. Warunki zamienne jednak nie mogą powodować zagrożenia życia ludzi lub bezpieczeństwa mienia, ograniczenia dostępności dla osób niepełnosprawnych oraz nie powinny powodować pogorszenia warunków zdrowotno-sanitarnych i użytkowych, a także stanu środowiska.

Prawo budowlane nie wymaga pozwolenia na budowę przy wykonywaniu pochylni przeznaczonych dla osób niepełnosprawnych. Jednoznacznie wskazuje składowe projektu architektoniczno-budowlanego, określającego funkcję, formę i konstrukcję obiektu, w tym opis dostępności dla osób niepełnosprawnych.

Organ nadzoru budowlanego, w myśl Prawa budowlanego, przeprowadza również obowiązkowe kontrole budowy w celu stwierdzenia prowadzenia jej zgodniez ustaleniami i warunkami określonymi w pozwoleniu na budowę, w tym zapewnienia warunków niezbędnych do korzystania z tego obiektu przez osoby niepełnosprawne, w szczególności poruszające się na wózkach inwalidzkich. Kontrole dotyczą obiektów użyteczności publicznej i budynków mieszkalnych wielorodzinnych. 
Innym bardzo ważnym aktem prawnym, traktującym o dostosowaniu budynków do potrzeb osób niepełnosprawnych, jest rozporządzenie Ministra Infrastruktury w sprawie warunków technicznych, jakim powinny odpowiadać budynki i ich usytuowanie (Dz.U. 2013, poz. 1409). Obejmuje ono kwestie związane z wejściami do budynków, miejscami postojowymi, parkingowymi, bramami i furtkami w ogrodzeniach oraz wyposażeniem budynków w dźwigi osobowe, drzwi wejściowe, pochylnie i odpowiednio zagospodarowane pomieszczenia higieniczno-sanitarne.

Wymienione akty prawne dotycza przystosowania obiektów użyteczności publicznej dla osób niepełnosprawnych. Sprecyzowano je tak, aby ułatwić funkcjonowanie w społeczeństwie tym osobom, w szczególności poruszającym się na wózkach inwalidzkich. Przepisy te nie mogą być lekceważone przez projektantów, wykonawców czy inwestorów.

Istnieją jednak czynniki, które powodują, że problem niepełnosprawności w budownictwie wystęuje. Powstają „,bariery” dla łatwego dostępu do budynków. Głównym czynnikiem jest postawa inwestorów czy projektantów: chęć zaoszczędzenia środków i trud- ność postawienia się na miejscu osób niepełnosprawnych. Trudność wyobrażenia sobie codziennego życia osób niewidomych czy poruszających się na wózkach inwalidzkich. Brak tego zrozumienia w społeczeństwie wpływa na błędy projektowe i niedokładność wykonawstwa.

\section{BADANIE DOSTĘPNOŚCI OBIEKTÓW UŻYTECZNOŚCI PUBLICZNEJ DLA OSÓB NIEPEŁNOSPRAWNYCH}

W celu zbadania barier architektonicznych, $\mathrm{z}$ jakimi muszą zmagać się osoby niepełnosprawne w codziennym życiu, przeprowadzono anonimową ankietę wśród osób niepełnosprawnych. Badanymi byli członkowie Katolickiego Stowarzyszenia Osób Niepełnosprawnych i Ich Przyjaciół „Klika” w Krakowie, uczniowie Policealnej Szkoły Integracyjnej Masażu Leczniczego nr 2 w Krakowie oraz przypadkowo napotkane osoby niepełnosprawne. W badaniu łącznie wzięło udział 35 osób, w tym 10 kobiet (28,6\% badanych) i 25 mężczyzn ( $71,4 \%$ badanych). W poniższej tabeli przedstawiono skwantyfikowana strukturę ankietowanej grupy.

Tabela. Osoby niepełnosprawne biorące udział w badaniu

Table. Disabled people participating in the survey

\begin{tabular}{lcc}
\hline $\begin{array}{l}\text { Rodzaj niepełnosprawności } \\
\text { Type of disability }\end{array}$ & $\begin{array}{c}\text { Liczba osób badanych } \\
\text { Number of people examined }\end{array}$ & $\begin{array}{c}\text { Udział w sumie badanych } \\
\text { Share in respondents } \\
(\%)\end{array}$ \\
\hline $\begin{array}{l}\text { Niewidomi lub słabowidzący } \\
\text { Blind or visually impaired }\end{array}$ & 15 & 42,9 \\
\hline $\begin{array}{l}\text { Głuchoniemi, głusi lub niedosłyszący } \\
\text { Deaf-mute, deaf or hearing impaired }\end{array}$ & 3 & 8,6 \\
\hline $\begin{array}{l}\text { Niepełnosprawni ruchowo poruszający się na wózku inwalidzkim } \\
\text { Disabled persons using a wheelchair }\end{array}$ & 13 & 37,1 \\
\hline $\begin{array}{l}\text { Niepełnosprawni ruchowo nie poruszający się na wózku inwalidzkim } \\
\text { Disabled persons not using a wheelchair }\end{array}$ & 1 & 2,9 \\
\hline $\begin{array}{l}\text { Niepełnosprawni intelektualnie } \\
\text { Intellectually disabled }\end{array}$ & 1 & 2,9 \\
\hline $\begin{array}{l}\text { Inne schorzenia } \\
\text { Other illnesses }\end{array}$ & 3 & 8,6 \\
\hline & 35 & Suma - In total \\
\hline
\end{tabular}


Przedział wiekowy badanych wynosił od 19 do 60 lat, a 8,6\% z nich nigdy nie poruszało się samodzielnie bez udziału osób trzecich. Poniżej przedstawiono pytania $\mathrm{z}$ ankiety oraz odpowiedzi na nie $\mathrm{w}$ formie wykresów.
1. Proszę wymienić najczęściej występujące bariery architektoniczne w budynkach użyteczności publicznej na terenie Krakowa oraz określić stopień ich trudności w skali od 0 (nigdy nie występują) do 5 (bardzo często występują).

- schody

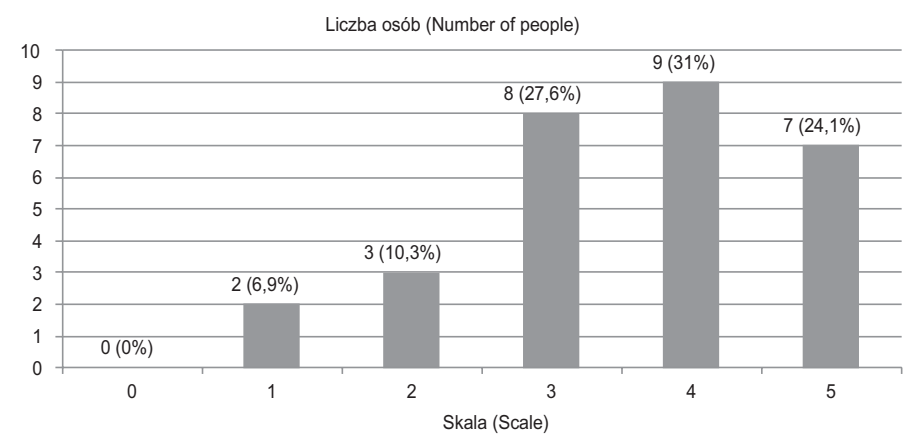

Rys. 1. Bariery architektoniczne - schody

Fig. 1. Architectural barriers - stairs

- wysokie progi

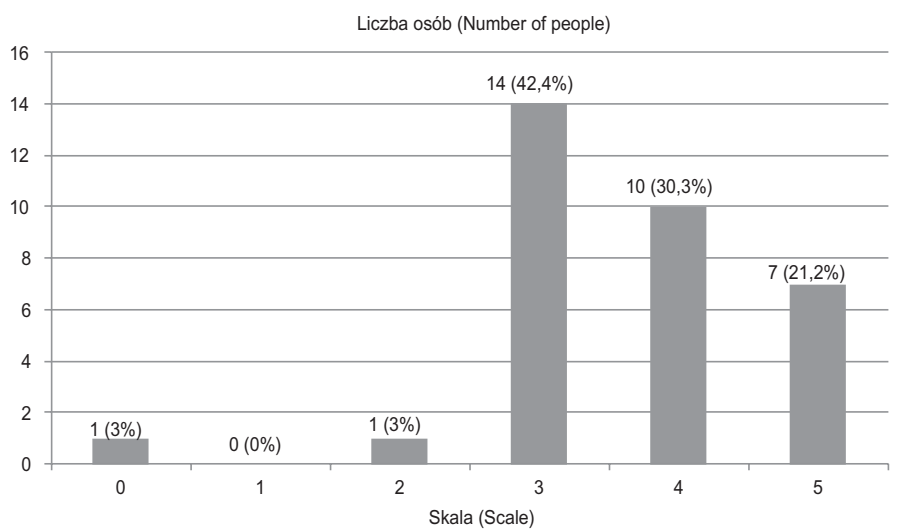

Rys. 2. Bariery architektoniczne - wysokie progi

Fig. 2. Architectural barriers- high thresholds

- brak podjazdu

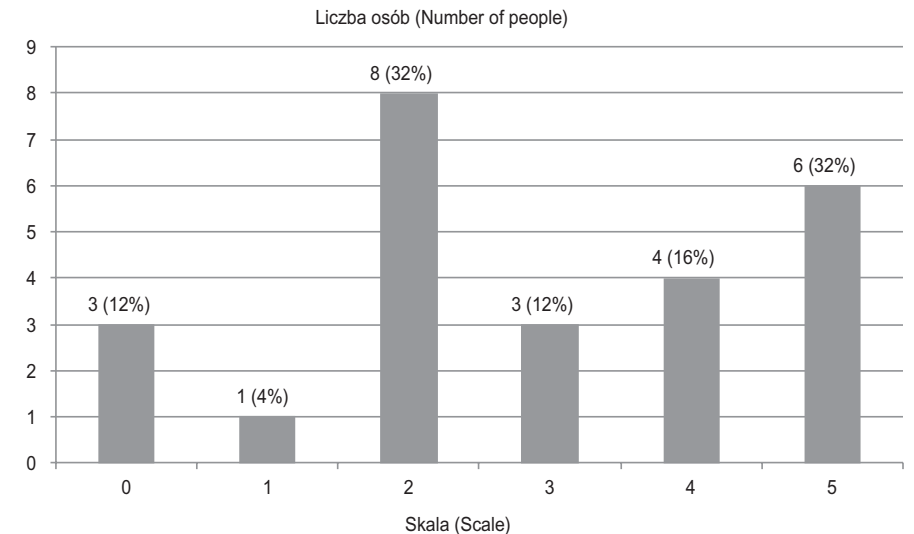

Rys. 3. Bariery architektoniczne - brak podjazdu

Fig. 3. Architectural barriers - no driveway 
Drozd, W. (2019). Analiza dostępności niektórych obiektów użyteczności publicznej dla osób niepełnosprawnych. Acta Sci. Pol. Architectura 18 (1), 109-118, DOI: 10.22630/ASPA.2019.18.1.13

- zbyt wąski lub zbyt stromy podjazd

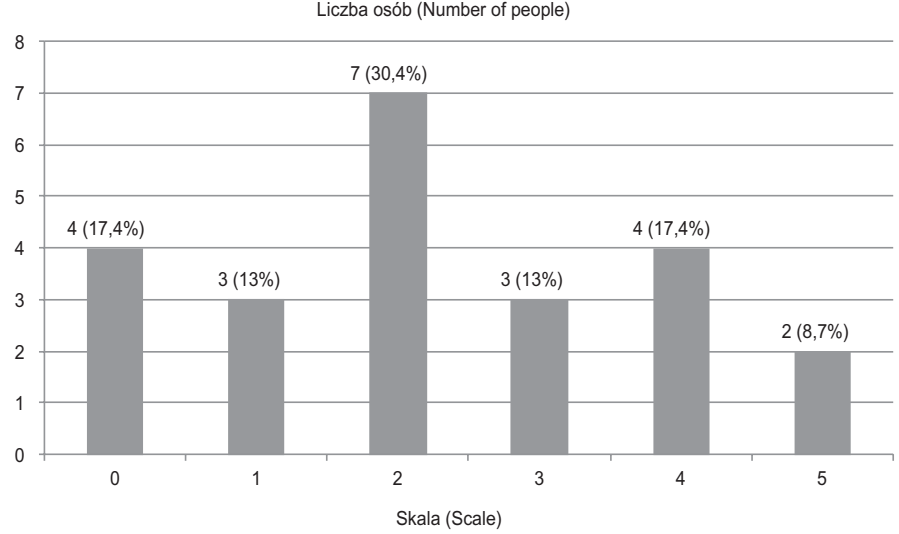

Rys. 4. Bariery architektoniczne - wąski lub stromy podjazd

Fig. 4. Architectural barriers - a narrow or steep driveway

- brak windy

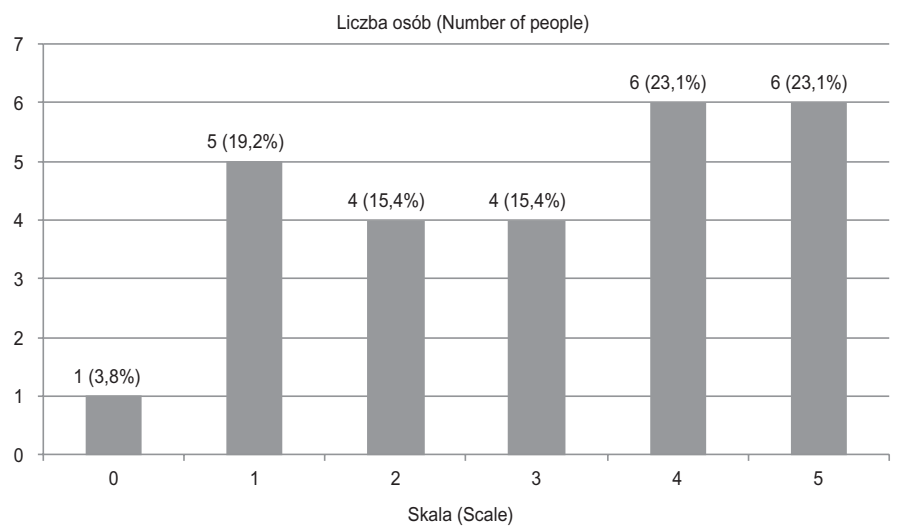

Rys. 5. Bariery architektoniczne - brak windy

Fig. 5. Architectural barriers - no elevator

- brak drzwi automatycznych

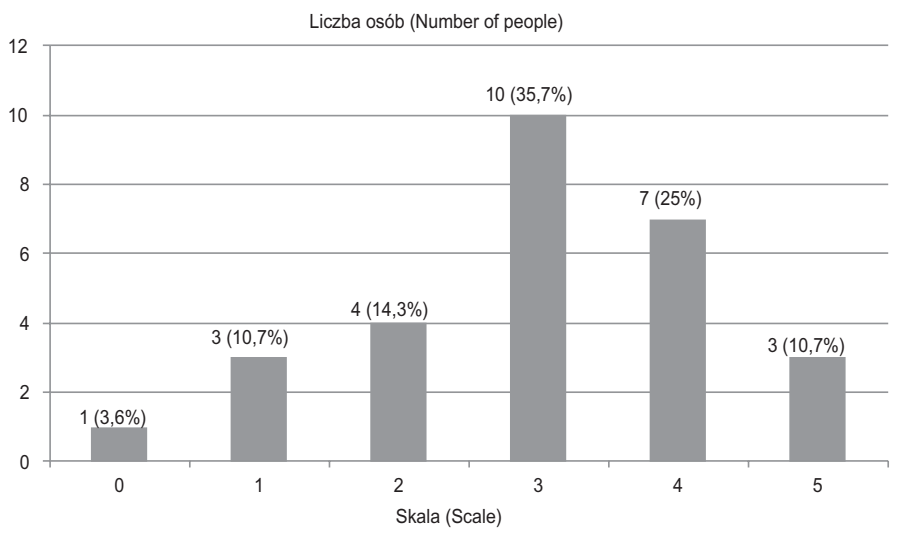

Rys. 6. Bariery architektoniczne - brak drzwi automatycznych

Fig. 6. Architectural barriers - no automatic doors 
Drozd, W. (2019). Analiza dostępności niektórych obiektów użyteczności publicznej dla osób niepełnosprawnych. Acta Sci. Pol. Architectura 18 (1), 109-118, DOI: 10.22630/ASPA.2019.18.1.13

- brak możliwości zaparkowania samochodem

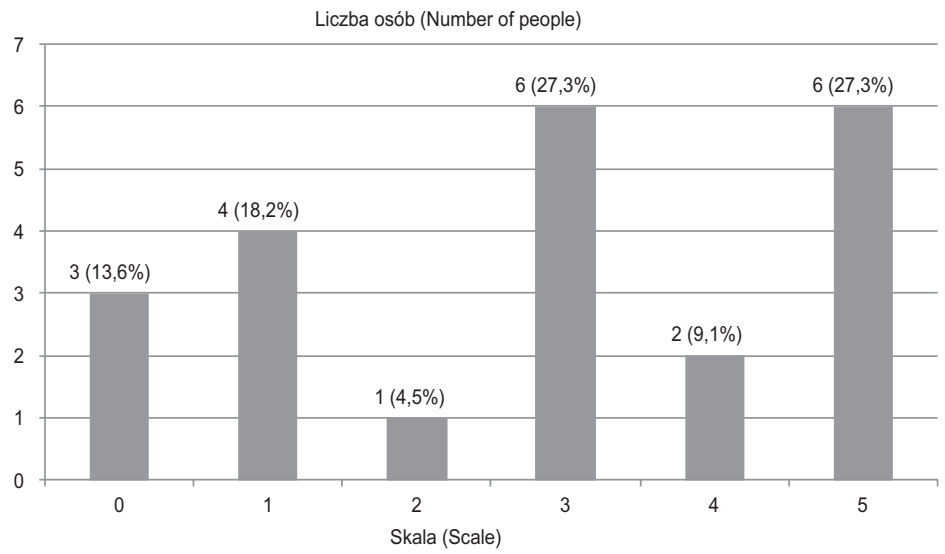

Rys. 7. Bariery architektoniczne - brak możliwości zaparkowania samochodem

Fig. 7. Architectural barriers - no possibility to park the car

2. Proszę wymienić najczęściej występujące bariery architektoniczne w aptekach.

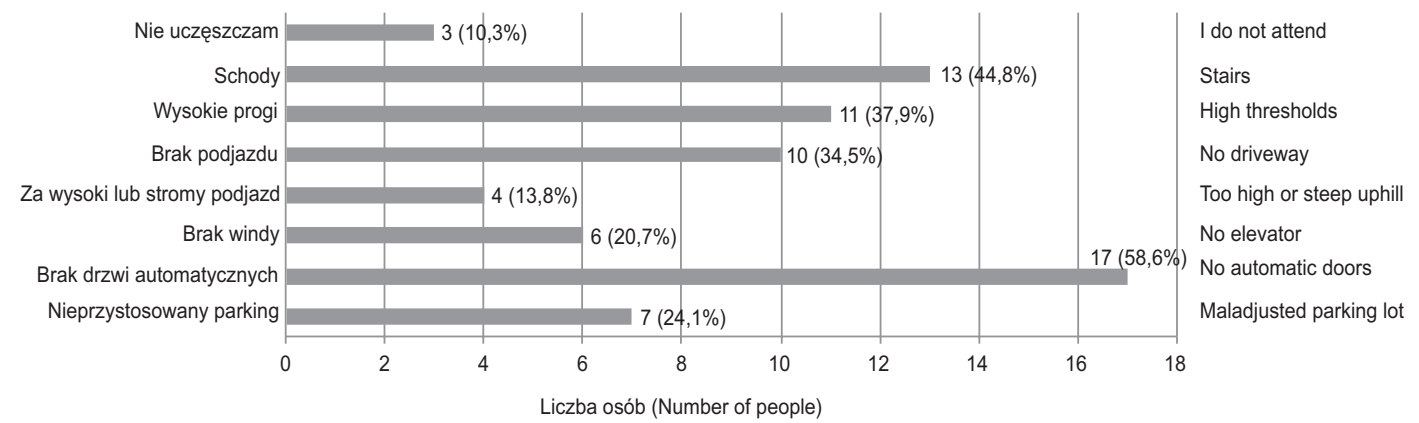

Rys. 8. Bariery architektoniczne występujące w aptekach

Fig. 8. Architectural barriers occurring in pharmacies

3. Proszę wymienić najczęściej występujące bariery architektoniczne w urzędach pocztowych.

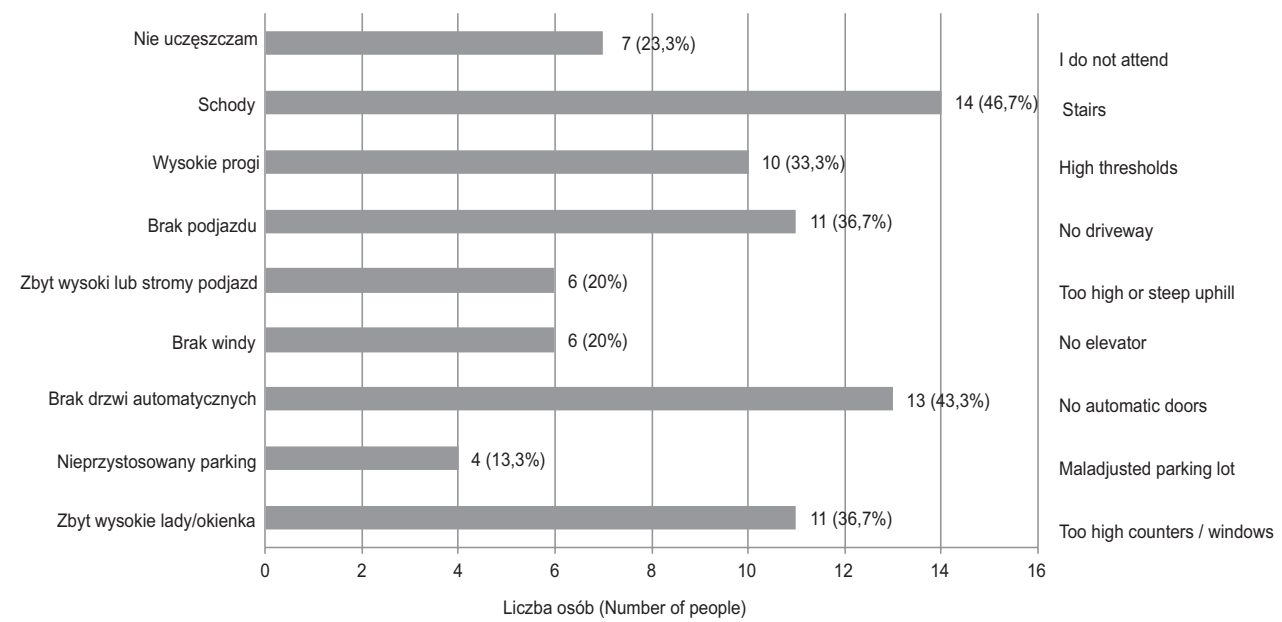

Rys. 9. Bariery architektoniczne występujące w urzędach pocztowych

Fig. 9. Architectural barriers in post offices 
Drozd, W. (2019). Analiza dostępności niektórych obiektów użyteczności publicznej dla osób niepełnosprawnych. Acta Sci. Pol. Architectura 18 (1), 109-118, DOI: 10.22630/ASPA.2019.18.1.13

4. Proszę wymienić najczęściej występujące bariery architektoniczne w budynkach handlowych.

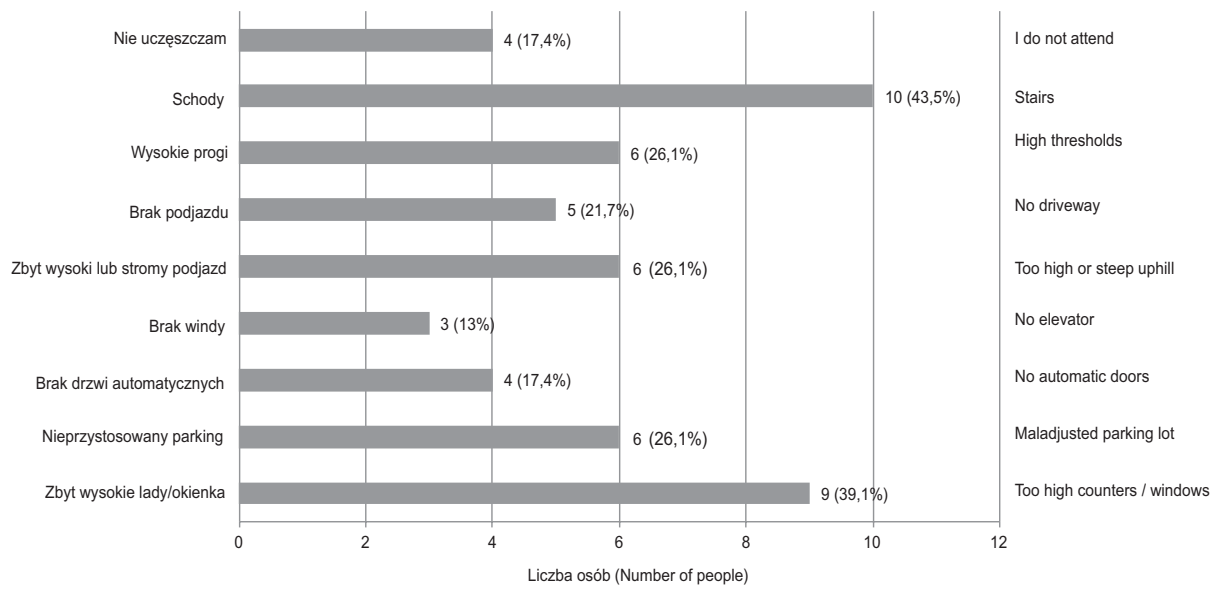

Rys. 10. Bariery architektoniczne występujące w obiektach związanych z handlem

Fig. 10. Architectural barriers occurring in objects related to trade

5. Proszę wymienić najczęściej występujące bariery architektoniczne w urzędach.

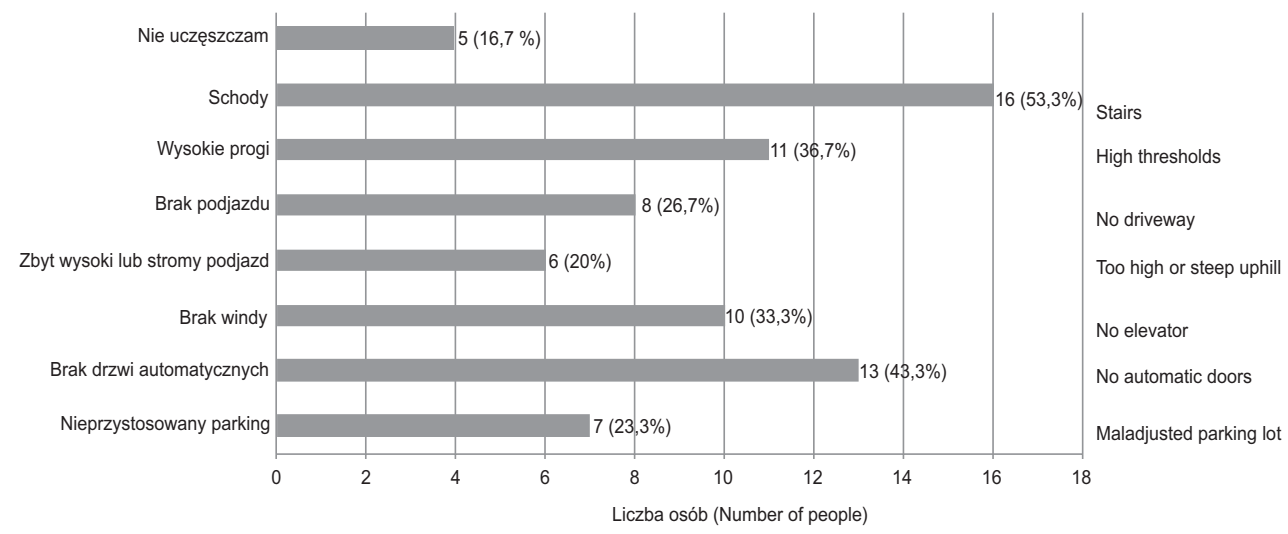

Rys. 11. Bariery architektoniczne występujące w urzędach i innych instytucjach

Fig. 11. Architectural barriers occurring in offices and other institutions

6. Proszę wymienić najczęściej występujące bariery architektoniczne w komisariatach policji.

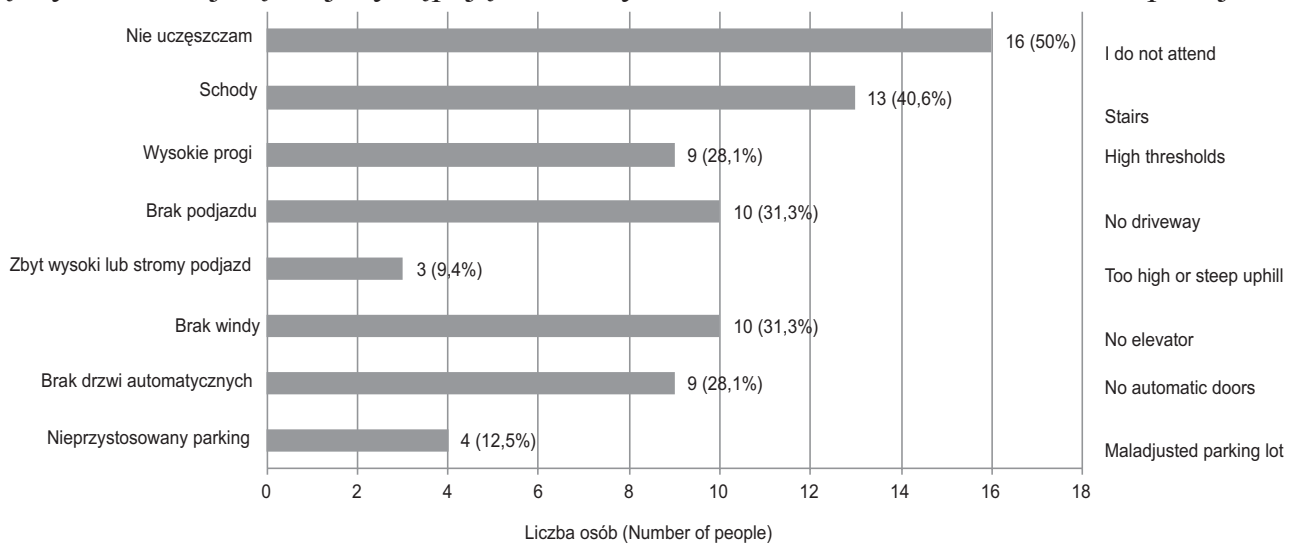

Rys. 12. Bariery architektoniczne występujące na komisariatach policji

Fig. 12. Architectural barriers occurring at police stations 
Drozd, W. (2019). Analiza dostępności niektórych obiektów użyteczności publicznej dla osób niepełnosprawnych. Acta Sci. Pol. Architectura 18 (1), 109-118, DOI: 10.22630/ASPA.2019.18.1.13

7. Proszę wymienić najczęściej występujące bariery architektoniczne w szpitalach i przychodniach lekarskich.

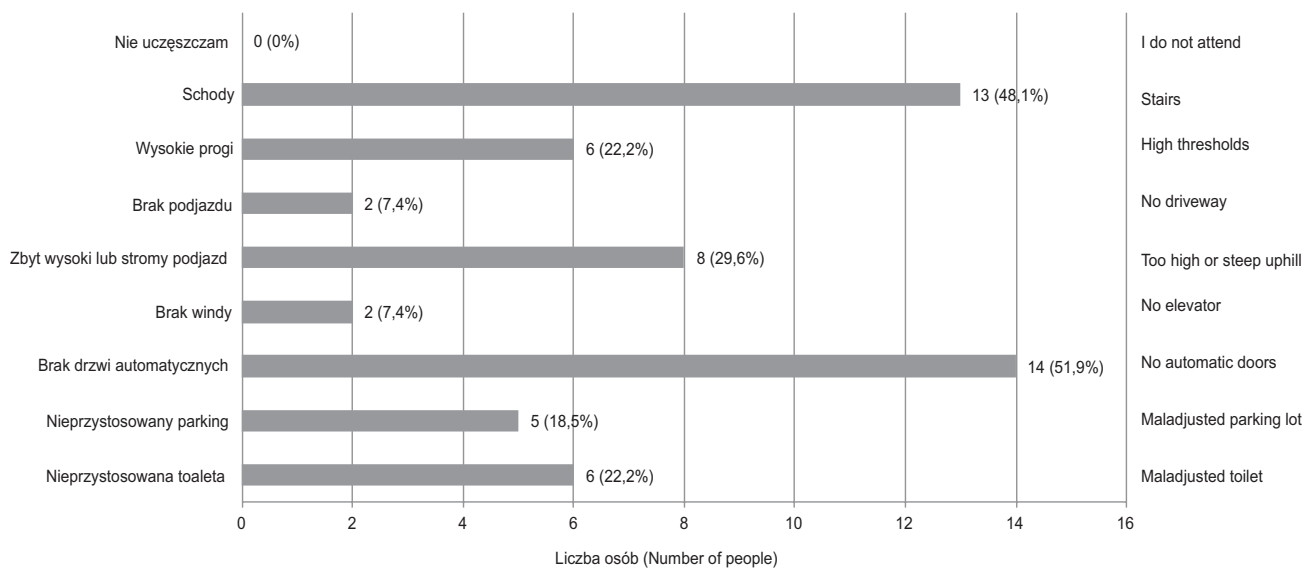

Rys. 13. Bariery architektoniczne występujące w szpitalach i przychodniach lekarskich

Fig. 13. Architectural barriers occurring in hospitals and outpatient clinics

8. Proszę wymienić najczęściej występujące bariery architektoniczne na dworcach PKP i PKS.

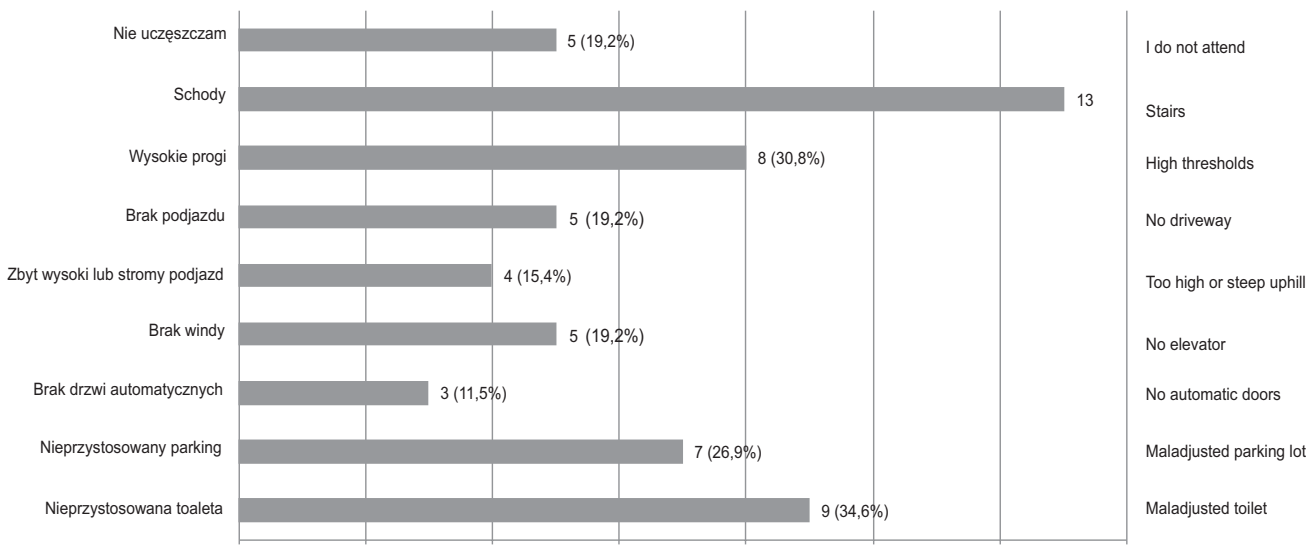

Rys. 14. Bariery architektoniczne występujące na dworcach PKP i PKS

Fig. 14. Architectural barriers occurring at railway and bus stations

9. Czy uważa Pan/Pani, że problem niepełnosprawności jest pomijany w budownictwie?

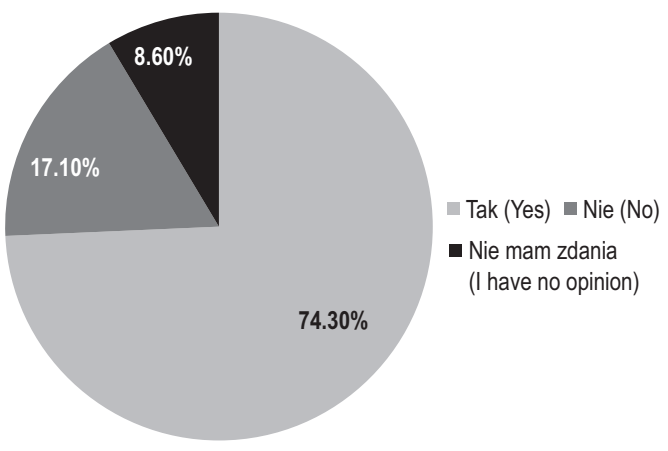

Rys. 15. Niepełnosprawność pomijana w architekturze

Fig. 15. Disability overlooked in architecture 
Stosowanie drzwi automatycznych nie jest wymagane $\mathrm{w}$ przepisach, jednak osoby niewidome oraz osoby poruszające się na wózku inwalidzkim uznały, że stosowanie takiego rozwiązania znacznie ułatwiłoby im wejście do budynków. Osoby niewidome zwracały uwagę na zagospodarowanie toalet w miejscach publicznych. Uznały, że znacznie łatwiej byłoby im odnaleźć dozownik z mydłem, gdyby znajdował się on zawsze np. po prawej stronie umywalki. Taką zasadę należałoby zastosować również do ręczników papierowych, suszarek lub papieru toaletowego. Bardzo przydatne okazałyby się dla osób niewidomych oznaczenia podłogowe w formie szyn podłogowych tak, aby łatwiej było im zlokalizować, gdzie zaczynają się i kończą się schody lub tak, aby wyznaczały drogę. Niewidomi nie wiedza, kiedy kończy się korytarz lub kiedy następuje zakręt. Prowadzenie szyn podłogowych oraz zastosowanie poręczy na ścianach zdecydowanie ułatwiłoby sprawne poruszanie się, szczególnie w dużych obiektach.

Osoby niewidome podczas badania ankietowego stwierdziły, że w wielu obiektach brakuje komunikatów w języku Braille’a, np. nad klamką każdych drzwi. W taki sposób znacznie łatwiej byłoby im znaleźć docelowy numer pokoju, odczytać nazwisko osoby znajdujacej się w danym pokoju lub dostosować sie do krótkich komunikatów na drzwiach, jak: „ciągnij”, „pchnij” lub też dostać się do odpowiedniej toalety.

W miejscach o większej powierzchni takich jak galerie handlowe znacznym ułatwieniem byłoby stworzenie makiety, tak aby osoby niewidome mogły odczytać, gdzie i na jakim poziomie znajduje się poszukiwany przez nie obiekt.

Osoby słabo widzące podczas badania uwagę głównie przywiązywały do zbyt małych i niewyraźnych dla nich oznaczeń oraz braku grubej, żółtej taśmy na początku i na końcu schodów. Główną trudnością w pokonaniu wejścia do budynku są dla nich całe przeszklone drzwi. W tym przypadku zastosowanie np. grubej taśmy na drzwiach, na wysokości oczu byłoby dla nich sygnalizacją o przezroczystej przegrodzie.

\section{WNIOSKI}

Problematyka dostępności obiektów użyteczności publicznej dla osób niepełnosprawnych to obszar działań, jakie powinny być podejmowane przez inwestorów oraz urzędników, którzy na co dzień mają styczność i trudność z interpretacją przepisów. Najważniejszym aspektem jest niepomijanie i niebagatelizowanie przepisów zarówno w etapie projektowania, jak i wykonywania obiektów, tak aby finalnym efektem była realizacja budynku dostępnego dla osób niepełnosprawnych.

W celu zniwelowania barier architektonicznych występujących w obiektach budowlanych w społeczeństwie należy przede wszystkim zacząć od zwiększania świadomości ludzi i pokazaniu im, na czym polega niepełnosprawność oraz jak te osoby funkcjonują w życiu codziennym. Nie można zapomnieć, że nie każda osoba niepełnosprawna jest inwalidą od urodzenia. Niektóre osoby uległy wypadkom lub innym zdarzeniom losu, przez co teraz są w pewien sposób niedysponowane. Wprowadzenie obowiązkowych szkoleń dla inżynierów i projektantów w zakresie dostępności obiektów dla osób niepełnosprawnych powinno odbywać się w każdym miejscu pracy. Szkoły budowlane lub uczelnie kształcące na kierunku budownictwo i pokrewnych także powinny poszerzać wiedzę uczniów i studentów w tym zakresie.

Obowiązujące Prawo budowlane nie pozostawia wątpliwości co do tego, że wszystkie budynki użyteczności publicznej powinny zostać przystosowane dla osób niepełnosprawnych, a w szczególności dla osób poruszających się na wózkach inwalidzkich.

\section{PIŚMIENNICTWO}

[b.a.] (2003). Raport. Życie usłane schodami. Integracja 2.

Gołuch, A. (1995). Budownictwo dla osób upośledzonych fizycznie i inwalidów. Gdańsk: Kanon.

Grabowska-Pałecka, H. (2004). Niepetnosprawni w obszarach $i$ obiektach zabytkowych. Problemy dostepności. Kraków: Wydawnictwo PK.

GUS (2017). Rocznik Demograficzny 2017. Warszawa. 
Jaranowska, K. (1983). Adaptacja mieszkań dla inwalidów. Warszawa: Wydawnictwo Spółdzielcze.

Meyer-Bohe, W. (1998). Budownictwo dla osób starszych $i$ niepetnosprawnych. Warszawa: Arkady.

Piasecki, M. i Stępniak, M. (1998). Standardowe zasady wyrównywania szans osób niepetnosprawnych. Lublin: Fundacja Fuga Mundi.
Rozporządzenie Ministra Infrastruktury z dnia 12 kwietnia 2002 r. w sprawie warunków technicznych, jakim powinny odpowiadać budynki i ich usytuowanie (Dz.U. $2002 \mathrm{nr} 75$, poz. 690).

Ustawa z dnia 7 lipca 1994 r. Prawo budowlane (Dz.U. 2013, poz. 1409).

\section{ANALYSIS OF AVAILABILITY OF SELECTED PUBLIC UTILITY FACILITIES FOR DISABLED PEOPLE}

\section{ABSTRACT}

The article discusses the issue of accessibility of public facilities for people with disabilities. In this context, it includes the analysis of provisions contained in legal acts and the analysis of selected public buildings in Krakow. In the methodological scope, a survey was conducted among disabled people. Due to the large scale of the problem, this topic seems to be as justified as possible.

Key words: people with disabilities, public facilities, accessibility 